\title{
Financial sustainability of social enterprise in Central and Eastern Europe
}

\author{
Daniela STAICU \\ The Bucharest University of Economic Studies, Business Administration Doctoral School, \\ Bucharest, Romania \\ danielastaicu@gmail.com
}

\begin{abstract}
Recent years have seen a burgeoning interest in social enterprise across Europe. In Central and Eastern European countries, the transition to a market economy stimulated civil society initiatives, and opened new pathways for entrepreneurial initiatives, including the pioneering establishment of the first social enterprises. Eight of the Central and Eastern European countries studied acknowledge the functioning of approximately 24000 social enterprises 'hidden' among a variety of existing legal forms, out of which 15172 associations and foundations undertaking some economic activity. Relatively little consideration has been given to the longer-term growth and performance of these hybrid organizational forms. To succeed, these ventures must adhere to both social goals and financial constraints. It implies that common forces from multiple actors - government and other public bodies, banks, corporations, investment funds as well as individuals join efforts. Business failure among social enterprises has been attributed to various difficulties related to size, a lack of resources, and finance and funding issues. It is essential to understand which revenue streams ensure financial sustainability in the case of the social enterprise. This paper analyzes the entrepreneurial dimension of social enterprise activity in eight Central and East European countries: Bulgaria, Croatia, the Czech Republic, Hungary, Poland, Romania, Slovakia, and Slovenia, addressing the question of social enterprise revenue streams. Most social enterprises examined are aware of the need to insure financial stability to their social mission and are actively securing and combining a blend of income streams, in order to avoid overdependence on one source of income and insure sustainability. None of the countries are solely depending on market sources. Research limitations were encountered when analyzing the variety of revenue streams due to the fact that some country reports presented also the dimension of a specific revenue, whereas others do not comprise specific numbers.
\end{abstract}

Keywords: social enterprise, Central and Eastern Europe, financial sustainability, revenue streams, entrepreneurship dimension.

\section{Introduction}

Recent years have seen a burgeoning interest in social enterprise across Europe, strongly driven by a growing recognition of the role social enterprise can play in tackling societal and environmental challenges and fostering inclusive growth (Directorate-General for Employment, Social Affairs and Inclusion, 2015), representing 10\% of all European businesses, with 2 million undertakings and 6\% of EU's employment (European Economic and Social Committee, 2011). The interest in social enterprise follows a decade of growing recognition by local and national governments and international organizations of the role of the social economy, the non-profit sector, the solidarity economy or the third sector (Borzaga and Defourny, 2001).

A social enterprise is an operator in the social economy whose main objective is to have a social impact rather than make a profit for their owners or shareholders. It operates by providing goods and services for the market in an entrepreneurial and innovative fashion and uses its profits primarily to achieve social objectives. It is managed in an open 
and responsible manner and, in particular, involve employees, consumers and stakeholders affected by its commercial activities (European Economic and Social Committee, 2011).

In Central and Eastern Europe, social enterprises legally functioning as associations and foundations with commercial activities have the highest activity with $62 \%$ of the total social enterprises legal forms (Staicu, 2017). The percentage of those which tackle the entrepreneurial dimension out of all non-governmental organisations is low as $0,24 \%$ in countries like Bulgaria, exception is Hungary where $100 \%$ of the non-governmental organisations have an economic dimension due to the fact that Hungary acknowledges nonprofit companies with social aims as social enterprises (European Commission, 2014g)). This insight has prompted an active search for readily scalable and replicable business models. However, relatively little consideration has been given to the longer-term growth and performance of these hybrid organizational forms. (Blundel et al., 2015).

The dual mission to achieve financial sustainability and create social value by integrating the socially excluded and disadvantaged into the workplace categorizes a social firm as a social enterprise (Borzaga and Defourny, 2001).

Typically, the aim is to benefit a specific group of people, permanently transforming their lives by altering a prevailing socioeconomic equilibrium that works to their disadvantage. The endeavor must also be financially sustainable. Otherwise the new socioeconomic equilibrium will require a constant flow of subsidies from taxpayers or charitable givers, which are difficult to guarantee indefinitely. (Obsberg and Sally, 2015).

Social enterprise strategies to generate revenue from commercial activity, e.g. trading goods and services and contracting for services, share some overlap with organizations in the private and public sectors (Wallace, 1999), yet are distinct from traditional non-profit organizations that rely on grants, donations and bequests. Social enterprises might rely on a combination of unearned income and commercial revenue or rely completely on trading income to meet their social objectives (Doherty et al., 2014). Social enterprises are good at managing resource dependence and use their community embeddedness and relational ties with stakeholders to secure external resources that, in turn, create opportunities for social action (Dacin et al., 2010).

Business failure among social enterprises has been attributed to various difficulties related to size, a lack of resources, and finance and funding issues. Other prominent issues reported include a lack of qualified staff, inadequate premises, and cash flow difficulties (Coburn and Rijsdijk , 2010).

Understanding the need for different types of well-targeted financing and how they best suit the reality of social enterprises in their endeavor to achieve a long-lasting social or environmental mission is crucial. As social enterprising emerges in the interface between traditional sectors and explore this hybridity, financing must nevertheless match this demand. It implies that common forces from multiple actors - government and other public bodies, banks, corporations, investment funds as well as individuals all over the world join to make this kind of business surge in spite of its complexity (Alamaa and Le Coq, 2017).

\section{Literature review}

The definition developed by the European Commission as part of the Social Business Initiative which ran from 2011 to 2014, could be used to distinguish social enterprises from mainstream enterprises and traditional social economy entities. (European Commission, 
2014a). These are private organisations that typically pursue goals other than profit: their main purpose is not to generate financial gains for their owners or stakeholders but to provide goods and services either to their members or to the community at large (Directorate-General for Employment, Social Affairs and Inclusion, 2013). A social enterprise involves all employees, consumers and third parties which are affected by its social and economic activities (Păunescu et al., 2016).

PICBE $\mid 909$

This definition incorporates the three key dimensions of a social enterprise that have been developed over the last decade through a body of European academic and policy literature: an entrepreneurial dimension, a social dimension, a governance dimension. (European Commission, 2014a). Each of the above dimensions were operationalized by developing a set of core criteria that an organisation must meet in order to be categorised as a social enterprise under the EU definition.

Table 1. Social enterprise core criteria literature frequency

\begin{tabular}{|l|l|l|l|r|}
\hline $\begin{array}{l}\text { Social } \\
\text { enterprise } \\
\text { dimension }\end{array}$ & $\begin{array}{l}\text { Core criteria that an organisation } \\
\text { must meet to be categorised as a } \\
\text { social enterprise }\end{array}$ & $\begin{array}{l}\text { Core criteria } \\
\text { reformulated for } \\
\text { literature review }\end{array}$ & Sources & References \\
\hline Entrepreneurial & must engage in economic activity & economic activity & $\mathbf{3 5}$ & $\mathbf{2 7 0}$ \\
\hline Social & $\begin{array}{l}\text { must pursue an explicit and primary } \\
\text { social aim }\end{array}$ & social aim & $\mathbf{2 0}$ & $\mathbf{1 3 2}$ \\
\hline
\end{tabular}

Source: Author's own processing

Though the definition of social enterprise puts emphasis on the social dimension, literature pays much attention is payed to the entrepreneurial dimension as seen in Table 1. In pursuing their social missions to make a social impact, social enterprises must remain sustainable; hence survive (Weerawardane et al., 2010). Although it has been reported that social enterprises increasingly seek finance from banks and venture capitalists (Bryson and Buttle, 2005), research by Sunley and Pinch (2012) found that the majority of social enterprises continued to rely on public-sector grants and were cautious about adding debt to their financial architecture.

Challenges arise in terms of measuring the social value, however, the markets in which social enterprises operate may put greater emphasis on economic value rather than social impact, and thus poor financial performance is punished more readily than poor social performance (Austin et al., 2006).

Social enterprises hybridity confers flexibility and legitimizes the acquisition of finance from both commercial sources and philanthropic sources (Chertok et al., 2008). As as most social enterprises are neither purely commercial nor philanthropy-dependent, they can leverage their dual mission to gain access to capital and secure preferential terms from financiers (Dees, 1998). This is especially valuable for early stage social enterprises and those operating in resource-scarce environments (Doherty, 2010).

More critically, two factors constrain social enterprises access to finance. First, the requirement to internalize social costs means that social enterprise generate less profit than might be created if they adopted full economic costing (VanSandt et al., 2009). Dees (1998) also identifies that the dual-pricing strategies typically adopted by social enterprises to set the price of refurbished furniture and electrical products on the basis of family 
income impacts on the financial performance of the social enterprise (Lumpkin et al., 2013 therefore propose that commercial ventures are more attractive to investors in terms of generating cash flow, and therefore have a greater chance of securing traditional bank loans or venture capital. More recent developments in social investment instruments have created new sources of finance for social enterprises. This new category of funds is financed by investors seeking opportunities to lend to organizations that create social value at the same time as generating some financial return (Nicholls, 2010). However, the relative newness of social investment funds on the financial landscape means that the volume of financial capital available is less than the traditional venture capital market (Nicholls, 2010).

\section{Methodology}

To achieve its main goal, to determine the financial sustainability dimension of social enterprises, the paper has two major objectives: (1) to determine the variety revenue streams of social enterprise in the countries examined; (2) to determine the entrepreneurial dimension of social enterprises in the countries examined by analyzing the level of public and private funding. Inquiries will be made on funding from investors and about the existence of solely depending on market sources, both private and public contracting.

For this purpose, data was collected from pertinent country reports, studies, laws, regulations: country reports published by the European Commission (under the title: "A map of social enterprises and their eco-systems in Europe, Country report") for each of the countries examined. Each report provides a non-exhaustive overview of the social enterprise landscape in each country studied, based on available information as of 2012 up to 2016, depending on country. Recently, the European Commission published a call for collaborators to update the country reports. No updated reports were published so far, therefore these country reports analyzed in this paper comprise the most recent information available.

The reports mention that although a range of stakeholders were interviewed to verify, update and supplement the information collected from secondary sources, it was not possible to consult all relevant stakeholders within the constraints of the study. The criteria used for analysis concerned the entrepreneurial dimension of the social enterprise through analyzing revenue streams of all countries studied classified in public and private funds.

Research limitations were encountered when comparing the variety of revenue resources due to the fact that some country reports presented the size of a specific revenue in the terms of percentage from the total revenue of a social enterprise, whereas others do not mention numbers.

\section{Results and discussion}

This section examines the financing of social enterprises in detail. While for-profit enterprises usually base their business models on revenues generated through trading activity, social enterprises rely on a range of revenue streams (Table 2) to finance their activities. 
Table 2. Social enterprise revenue streams

\begin{tabular}{|c|c|c|c|c|c|c|c|}
\hline \multirow{2}{*}{$\begin{array}{c}\begin{array}{c}\text { Type of } \\
\text { funds }\end{array} \\
\\
\begin{array}{c}\text { Source } \\
\text { of funds }\end{array} \\
\end{array}$} & \multicolumn{2}{|c|}{ Public funds } & \multicolumn{5}{|c|}{ Private funds } \\
\hline & $\begin{array}{c}\text { Public } \\
\text { contracting } \\
\text { (both } \\
\text { tenders and } \\
\text { direct } \\
\text { contracting) }\end{array}$ & $\begin{array}{c}\text { Grants } \\
\text { /subsidies }\end{array}$ & $\begin{array}{l}\text { Trading } \\
\text { activity }\end{array}$ & $\begin{array}{c}\text { Rental } \\
\text { income on } \\
\text { assets }\end{array}$ & $\begin{array}{c}\text { Fees } \\
\text { including } \\
\text { membership } \\
\text { fees }\end{array}$ & Sponsorship & $\begin{array}{c}\text { Others } \\
\text { (including } \\
\text { voluntary } \\
\text { and in-kind } \\
\text { contribu- } \\
\text { tions) }\end{array}$ \\
\hline $\begin{array}{c}\text { Czech } \\
\text { Republic }\end{array}$ & $33 \%$ & & $51.2 \%$ & & & & \\
\hline Bulgaria & $\begin{array}{l}\text { available, no } \\
\text { specific } \\
\text { numbers } \\
\text { given }\end{array}$ & & $\begin{array}{c}\text { available, } \\
\text { no specific } \\
\text { numbers } \\
\text { given }\end{array}$ & & $\begin{array}{l}\text { available, no } \\
\text { specific } \\
\text { numbers } \\
\text { given } \\
\end{array}$ & & \\
\hline Hungary & $42 \%$ & $\begin{array}{c}\text { available, no } \\
\text { specific } \\
\text { numbers } \\
\text { given } \\
\end{array}$ & $\begin{array}{c}\text { available, } \\
\text { no specific } \\
\text { numbers } \\
\text { given } \\
\end{array}$ & & $\begin{array}{l}\text { available, no } \\
\text { specific } \\
\text { numbers } \\
\text { given } \\
\end{array}$ & & \\
\hline Poland & $6,5 \%$ & $23 \%$ & $36 \%$ & & & & \\
\hline Romania & & $\begin{array}{l}\text { available, no } \\
\text { specific } \\
\text { numbers } \\
\text { given } \\
\end{array}$ & $57 \%$ & & & $\begin{array}{l}\text { available, no } \\
\text { specific } \\
\text { numbers } \\
\text { given }\end{array}$ & $\begin{array}{l}\text { available, no } \\
\text { specific } \\
\text { numbers } \\
\text { given }\end{array}$ \\
\hline Slovakia & & $\begin{array}{l}\text { available, no } \\
\text { specific } \\
\text { numbers } \\
\text { given }\end{array}$ & $\begin{array}{c}\text { available, } \\
\text { no specific } \\
\text { numbers } \\
\text { given }\end{array}$ & & & $\begin{array}{l}\text { available, no } \\
\text { specific } \\
\text { numbers } \\
\text { given }\end{array}$ & $\begin{array}{l}\text { available, no } \\
\text { specific } \\
\text { numbers } \\
\text { given }\end{array}$ \\
\hline Slovenia & & $\begin{array}{c}\text { available, no } \\
\text { specific } \\
\text { numbers } \\
\text { given } \\
\end{array}$ & $30-50 \%$ & & & $\begin{array}{l}\text { available, no } \\
\text { specific } \\
\text { numbers } \\
\text { given }\end{array}$ & $\begin{array}{l}\text { available, no } \\
\text { specific } \\
\text { numbers } \\
\text { given } \\
\end{array}$ \\
\hline Croatia & & $\begin{array}{l}\text { available, no } \\
\text { specific } \\
\text { numbers } \\
\text { given }\end{array}$ & $30-40 \%$ & $\begin{array}{c}\text { available, } \\
\text { no specific } \\
\text { numbers } \\
\text { given }\end{array}$ & $\begin{array}{c}\text { available, no } \\
\text { specific } \\
\text { numbers } \\
\text { given } \\
\end{array}$ & & \\
\hline
\end{tabular}

Source: Author's own processing

Social enterprises typically adopt a 'hybrid' business model they derive their revenues from a combination of: (1) market sources (the sale of goods and services to the public or private sector, table 3); (2) non-market sources (government subsidies and grants, private donations, non-monetary or in-kind contributions such as voluntary work etc.).

The main revenue streams of social enterprises can be described as follows:

(1) Revenue derived from public contracts: social enterprise contract with public authorities and agencies to receive fees for defined services ( 4 out 8 countries). The structure of these payments can be quite different, varying from direct payment by public authorities to social security systems, voucher systems, or indirect payment through thirdparty intermediaries; direct grants / subsidies: provided to social enterprises by public authorities e.g. grants for specific project-based activity, or employment subsidies which are 'compensation' for employing people with impaired work ability and for the resulting productivity shortfall (75\%);

(2) Revenue derived from market based revenue derived from private sources: through the sale of goods and services to other businesses and final consumers (100\%); membership fees $(37,5 \%)$, and sponsorship (25\%); and other forms of revenue include income from 
renting assets $(12,5 \%)$, prize money or income from endowed assets, and non-monetary forms such as in-kind donations (e.g. old IT equipment, food, building material) $(37,5 \%)$.

Table 3. Earned income derived by social enterprises from market services (including competitive public sector contracts)

\begin{tabular}{|c|c|}
\hline $\begin{array}{c}\text { Market income as a } \\
\text { share of total revenues }\end{array}$ & Exemplar countries \\
\hline Above $50 \%$ & Czech Republic, Romania \\
\hline $30 \%$ to $50 \%$ & Hungary, Poland, Slovenia, Croatia \\
\hline
\end{tabular}

PICBE | 912

For Bulgaria and Slovakia, no numbers are offered in the country reports, therefore it is impossible to assess the market income as a share of total revenues.

Where mapping data allows, and it is incomplete for many countries, it suggests that income derived from market sources varies by country and by organisational form: (1) In countries like the Czech Republic, Poland, Romania, Croatia, social enterprises derive a majority of their revenue from market sources and particularly from the sale of goods and services; (2) In other countries for which data are available (e.g. Hungary), the entrepreneurial dimension was found to be less strong with social enterprises deriving less than $50 \%$ of their revenue from market sources (e.g. In Hungary, almost all social enterprise forms are heavily reliant on continuous external financing (grants and subsidies), mostly from public funds. For non-profit organisations including associations, foundations as well as non-profit companies, external funding accounted $57 \%$ of the revenues in 2011, 42\% of which was paid from public money (European Commission, 2014g).

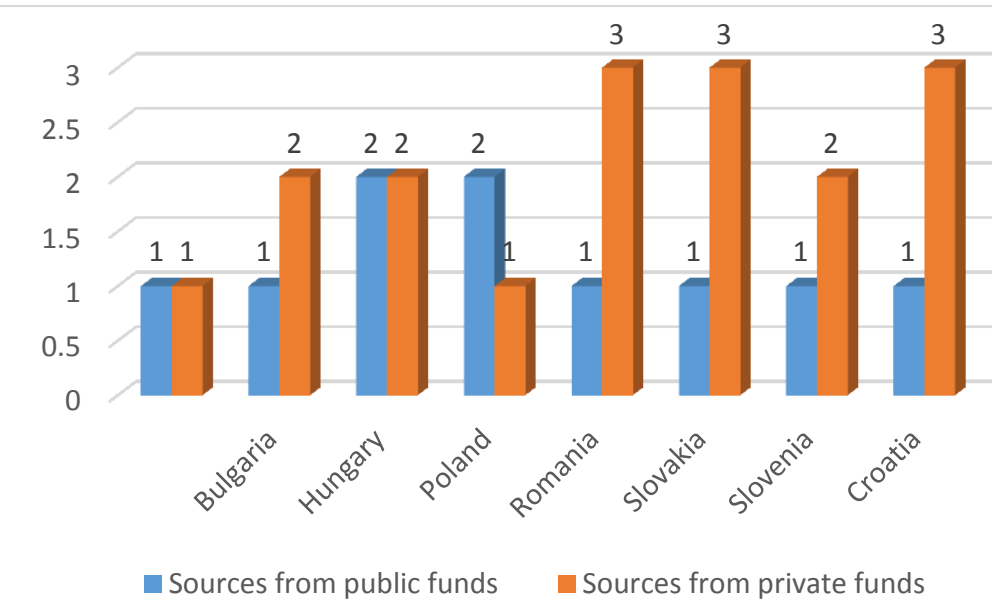

Figure 1. Social enterprise revenue streams per country analysis:Number and type of sources Source: Authors' own processing

In Poland, though public sector funding dominates the revenue streams of social enterprises (Figure 1) in terms of number of sources of funding (both public contracting 
$(6,5 \%)$ and public grants/subsidies (23\%)), the size of the public revenue stream $(29,5 \%)$ is inferior to the size of revenues generated through economic activity (36\%).

In Czech Republic and Romania, available data suggest that main source of income of social enterprises comes from private funds (51,2\% and $57 \%)$.

Since for the majority of the countries studied, reports do not specify the value of each type of revenue, it is difficult to assess the size of the revenue. Only measurements about the number of resources (public or private) can be done. Information about the size of market or non-market revenues is available only for a few countries. A standardized measurement system of revenue streams values need to be introduced for future mapping of social enterprise activity.

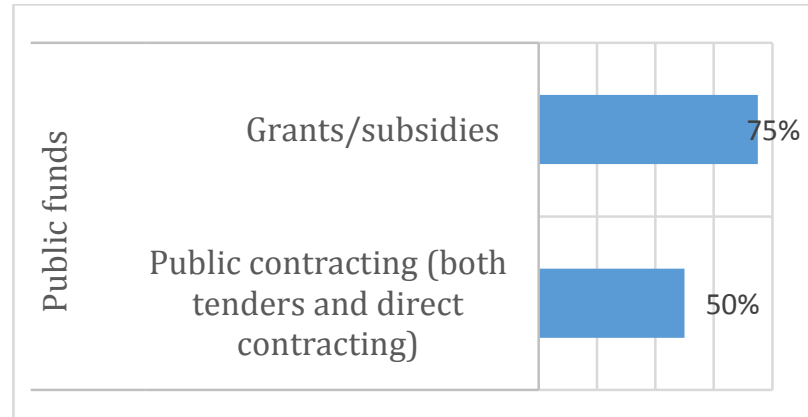

Figure 2. Social enterprise revenue streams analysis public funds resource allocation Source: Author's own processing

$75 \%$ of social enterprises have access to public grants of subsidies, compared to $50 \%$ with access to revenues from contracts with public institutions (Figure 2).

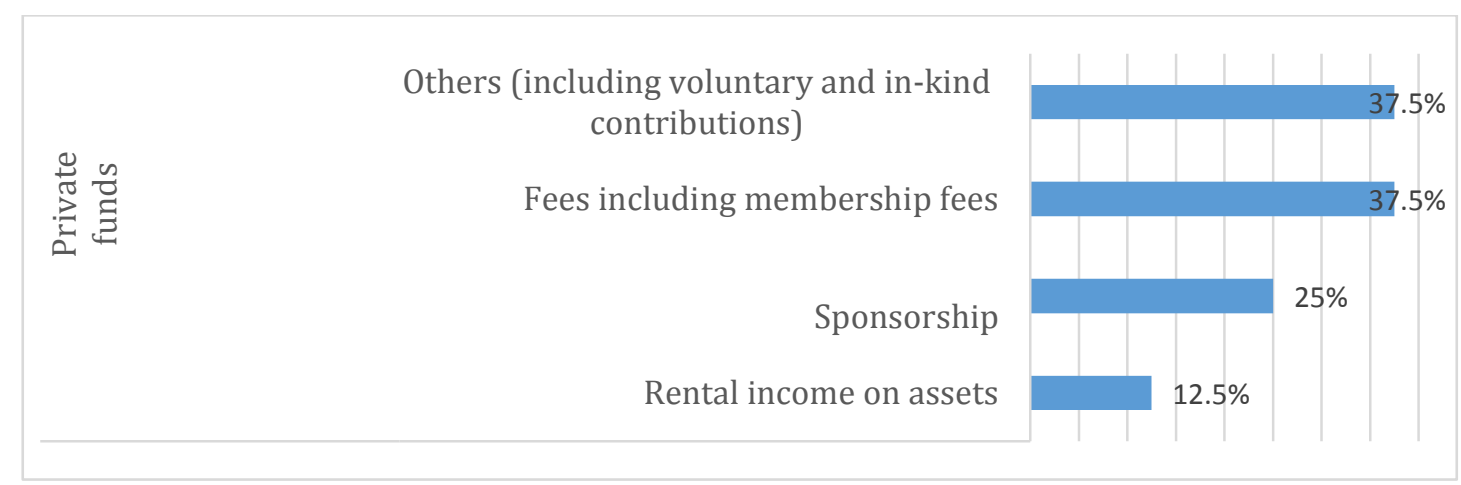

Figure 3. Social enterprise revenue streams analysis rivate funds resource allocation

Source: Authors' own processing

All social enterprises gain revenues from the trading activity (Table 2). Second private revenue stream is represented by voluntary and in-kind contributions and fees $(37,5 \%$ each) and the least 'profitable' is rental income on assets (Figure 3$)$.

There are indications in many countries that new entrepreneurial organisations are emerging, with the deliberate aim of achieving a social mission through the supply of services at a market price rather than through, say, the provision of employment opportunities of various types for disadvantaged people. This emergent trend, noted in 
countries such as Austria, Estonia, Spain, Germany, France, the UK, Latvia, Netherlands and Switzerland, trend supported by innovative forms of finance (for example, the growth of social impact investment) and networks to support the development of new business models (European Commission, 2014a).

From Table 1, we can conclude that none of the eight countries studied, this new style of enterprise, solely depending on market sources has arisen, as it has in more developed countries such as UK or Sweden, detailed information available in the country reports (European Commission, 2014a).

No reference is made in the sources analyzed about a new category of funds supplied by investors seeking opportunities to lend to organizations that create social value at the same time as generating some financial return.

\section{Conclusion}

A business recognises that profit is the oxygen that enables a business to survive and prosper and that it is a main indicator of business health. For a social enterprise, the aim is to benefit a specific group of people, permanently transforming their lives, having in mind that the endeavor must also be financially sustainable. The turbulent economic environment, forces social enterprises to face the ongoing challenge of sustainability. This challenge requires social enterprises to identify a business model which generates a balance between acquiring resources to build and maintain competitive advantage and using resources to engage with their key stakeholder groups.

All of the social enterprises examined are aware of the need to insure financial stability to their social mission and are actively securing and combining a blend of income streams. The ability to blend grants, preferential purchasing from the public sector, service contracts, voluntary contributions of time and money, and trading income is desirable is order to insure sustainability.

Reliance of social enterprises on the public sector can raise concerns about the long term sustainability of their business models in the face of austerity measures being implemented across countries, although evidence suggests the importance of the specificity of national context, activity and enterprise business model in shaping impacts.

All of the organisations recognised the importance of fulfilling the entrepreneurial dimension early and have actively sought to avoid overdependence on one source of income, such as a single funder or contract, or the public sector, but none of the eight countries studied are not solely depending on market sources.

No reference is made about a new category of funds supplied by investors seeking opportunities to lend to organizations that create social value at the same time as generating some financial return.

Research limitations were encountered when comparing the variety of revenue resources due to the fact that some country reports presented the size of a specific revenue, whereas others do not mention numbers. A standardized measurement system of revenue streams values need to be introduced for future mapping of social enterprise activity. Official aggregate and comparable data might help in determining financial sustainability of social enterprises across countries studied and lessons from one country might serve to the benefit of another. 


\section{References}

Alamaa C, Le Coq C. (2017). Mixing and Matching: The driving forces behind financing modes of social enterprises. Retrieved from www.seforis.eu/s/Deliverable-53policy-brief-SITE.pdf

Austin, J., Stevenson, H. and Wei-Skillern, J. (2006). Social and commercial entrepreneurship: same, different or both? Entrepreneurship Theory and Practice, 30 , pp. 1-22.

Blundel et al. (2014). Scaling and Replication of Social Ventures. Journal of Social Entrepreneurship, Volume 5, 146-174. doi.org/10.1080/19420676.2013.871325

Borzaga C., Defourny J. (2001). From third sector to social enterprise. The Emergence of Social Enterprise, London and New York, Routledge, pp. 350-370.

Bryson, J.M. and Buttle, B. (2005). Enabling inclusion through alternative discursive formations: the regional development of community development loan funds in the UK. The Services Industries Journal, 25, pp. 273-288.

Chertok, M., Hammoui, J. and Jamison, E. (2008). The funding gap. Stanford Social Innovation Review, 26, pp. 44-51.

Coburn J., Rijsdijk R. (2010). Evaluating the Success Factors for Establishing a Thriving Social Enterprise in Scotland. Retrieved from http://www.gov.scot/Publications/2010/11/23094200/0

Dacin, P.A., Dacin, M.T. and Matear, M. (2010). Social entrepreneurship: why we don't need a new theory and how we move forward from here. Academy of Management Perspectives, 24, pp. 37-57.

Dees, G. and Elias, J. (1998). The challenges of combining social and commercial enterprise. Business Ethics Quarterly, 8, pp. 165-178.

Directorate-General for Employment, Social Affairs and Inclusion. (2013). Social economy and social entrepreneurship, Social Europe guide, Volume 4. Luxembourg:

Publications Office of the European Union.

Directorate-General for Employment, Social Affairs and Inclusion. (2015). A map of social enterprises and their eco-systems in Europe. Luxembourg: Publications Office of the European Union. Retrieved from http://ec.europa.eu/social/.

Doherty B et al.. (2014). Social Enterprises as Hybrid Organizations: A Review and Research Agenda. International Journal of Management Reviews, Vol. 16, 417-436 (2014). doi:10.1111/ijmr.12028

European Commission. (2011). Social Business Initiative. Retrieved from http://ec.europa.eu/internal_market/social_business/docs/COM2011_682_en.pdf

European Commission. (2014a). A map of social enterprises and their eco-systems in Europe: Executive Summary. Retrieved from European Commission, Employment, Social Affairs \& Inclusion Website: http://ec.europa.eu/social/BlobServlet?docId=12988\&langId=en

European Commission. (2014b). A map of social enterprises and their eco-systems in Europe, Country Report: Bulgaria, European Commission. Retrieved from European Commission, Employment, Social Affairs \& Inclusion Website: http://ec.europa.eu/social/BlobServlet?docId=12990\&langId=en

European Commission. (2014c). A map of social enterprises and their eco-systems in 
Europe, Country Report: Romania. Retrieved from European Commission, Employment, $\quad$ Social Affairs \& Inclusion Website:

http://ec.europa.eu/social/BlobServlet?docId=13095\&langId=en

European Commission. (2014d). A map of social enterprises and their eco-systems in

Europe, Country Report: Slovenia. Retrieved from European Commission,

Employment, $\quad$ Social Affairs \& Inclusion Website:

http://ec.europa.eu/social/BlobServlet?docId=13000\&langId=en

European Commission. (2014e). A map of social enterprises and their eco-systems in

Europe, Country Report: Slovakia. Retrieved from European Commission,

Employment, Social Affairs \& Inclusion Website:

European Commission. (2014f). A map of social enterprises and their eco-systems in

Europe, Country Report: Czech Republic. Retrieved from European Commission,

Employment, $\quad$ Social Affairs \& Inclusion Website:

http://ec.europa.eu/social/BlobServlet?docId=13101\&langId=en

European Commission. (2014g). A map of social enterprises and their eco-systems in

Europe, Country Report: Hungary. Retrieved from European Commission,

Employment, $\quad$ Social Affairs \& Inclusion Website:

http://ec.europa.eu/social/BlobServlet?docId=13103\&langId=en

European Commission, Directorate-General for Employment, Social Affairs and Inclusion.

(2016). Social enterprises and their Eco-systems: developments in Europe.

Luxembourg: Publications Office of the European Union.

European Commission (2016a), A map of social enterprises and their eco-systems in

Europe, Country Report: Poland. Retrieved from European Commission,

Employment, Social Affairs \& Inclusion Website:

http://ec.europa.eu/social/BlobServlet?docId=16381\&langId=en

European Commission (2016b), A map of social enterprises and their eco-systems in

Europe, Country Report: Croatia. Retrieved from European Commission,

Employment, Social Affairs \& Inclusion Website:

http://ec.europa.eu/social/BlobServlet?docId=12991\&langId=en

European Commission Directorate-General for Employment, Social Affairs and Inclusion.

(2016c). Social enterprises and their eco-systems: A European mapping report

Updated country report: Slovakia. Retrieved from European Commission,

Employment, Social Affairs \& Inclusion Website:

ec.europa.eu/social/BlobServlet?docId=16382\&langId=en

Lumpkin, G.T. et al. (2013). Entrepreneurial processes in social contexts: how are they different, if at all? Small Business Economics, 40, pp. 761-783.

Nicholls, A. (2010b). The institutionalization of social investment: the interplay of investment logics and investor rationalities. Journal of Social Entrepreneurship, 1, pp. 70-100.

Obsberg S., Sally R.. (2015). Two Keys to sustainable Social Enterprise. Harvard Business Review. Retrieved from https://hbr.org/2015/05/two-keys-to-sustainable-socialEnterprise

Păunescu, C., Pascu, A.I., Pop, O. (2016). Întreprinderea socială: cum se distinge acest mod de a face afaceri față de alte întreprinderi? / Social Enterprise: How does this Way of doing Business differ from other Forms of Enterprise. Calitatea. Acces la succes/ 
Quality. Access to Success (Scientific Journal of Management Systems (CSRAC), 17(153), 23-27/108-110.

Staicu D. (2017). Policy framework and legal forms of social enterprise in Central and Eastern Europe. Proceedings of the International Conference on Business Excellence, Volume 11, Issue 1, pp. 875-883. ISSN (Online) 25589652. doi: https://doi.org/10.1515/picbe2017-0093

Sunley, P. and Pinch, S. (2012). Financing social enterprise: social bricolage or evolutionary entrepreneurialism? Social Enterprise Journal, 8, pp. 108-122.

Wallace, S.L. (1999). Social entrepreneurship: the role of social purpose enterprises in facilitating community economic development. Journal of Developmental Entrepreneurship, 4, pp. 153-174.

Weerawardena J. et al. (2010). Sustainability of nonprofit organizations: An empirical investigation. Journal of World Business 45 (4), 346-356. Retrieved from www.el sevier.com/locate/jwb 